Omelicheva, Mariya Y. Ethnic Dimension of Religious Extremism and Terrorism in Central Asia, International Political Science

Review, 2010 31(2): 167-186. Publisher's Official Version: <http://dx.doi.org/10.1177/0192512110364738>.

Open Access Version: <http://kuscholarworks.ku.edu/dspace/>.

[This document contains the author's accepted manuscript. For the publisher's version, see the link in the header of this document.]

\title{
Ethnic Dimension of Religious Extremism and Terrorism in Central Asia
}

\author{
Mariya Y. Omelicheva
}

\section{Paper citation:}

Omelicheva, Mariya Y. Ethnic Dimension of Religious Extremism and Terrorism in Central Asia, International Political Science Review, 2010 31(2): 167-186.

\section{Keywords:}

\section{Abstract:}


Omelicheva, Mariya Y. Ethnic Dimension of Religious Extremism and Terrorism in Central Asia, International Political Science Review, 2010 31(2): 167-186. Publisher's Official Version: <http://dx.doi.org/10.1177/0192512110364738>.

Open Access Version: <http://kuscholarworks.ku.edu/dspace/>.

International Political Science Review, 2010 31(2): 167-186.

\section{Ethnic Dimension of Religious Extremism and Terrorism in Central Asia}

Mariya Omelicheva, University of Kansas

The collapse of the Soviet Union unleashed a flood of religious activity in parts of Central Asia. Along with the moderate and traditional forms of the Islamic faith, radical Islam reemerged in the Muslim communities of the Central Asian republics. Although, people of all backgrounds have been drawn to radical Islam, Islamists have been less successful in gaining support in the communities of indigenous populations of Kyrgyzstan, Kazakhstan, and Turkmenistan, than among the Uzbek and Tajik minorities. What explains variation in the extent of support of radical Islamic groups by ethnic minorities in Central Asia?

Scholars have long been interested in examining the genesis and impact of Islamic threat on the regional stability and security of the individual Central Asian nations (see, for example, Malashenko and Olcott, 2001; Naumkin, 2005; Rashid, 2002; Sagdeev, 2000). Some have also been concerned that ethnicity might reemerge as a trigger for intra-state conflicts (Ahmedova and Leitich, 2001). Few, however, have attempted to juxtapose ethnicity and Islamic radicalism and systematically examine an ethnic dimension of religious extremism and political violence in Central Asia. ${ }^{1}$ In this study, I aim to illuminate the differences in the ethnic makeup of members and supporters of radical Islamic groups in the Central Asian states, and suggest explanations for this variation.

I contend that two related factors - the greater Islamicization of Uzbeks and Tajiks, and religious persecution of the ethnic minorities - have contributed to stronger support of Islamists by Uzbeks and Tajiks, than by other ethnic groups in Central Asia. 
For the purpose of this analysis, support for radical Islamic groups is defined broadly. It includes sharing the organizations' goals, which can be as specific as the goal of building the region-wide Islamic Caliphate, or as broad as the task of saving all Muslims from suffering incurred by the infidel rulers. Support for Islamists encompasses participation in various activities of peaceful and violent nature coordinated by radical Islamic groups. It also denotes the instances of identification and membership in radical religious organizations.

To explicate how Islamic identification promotes support for radical Islamic groups, this research relies on the tenets of social movement theory. The latter embraces an array of approaches that look at the structures of political opportunities, resource mobilization, and framing to explain why various forms of mobilization occur. In the context of this study, I treat radical Islamic movements as collective efforts to achieve political objectives outside of the sphere of established public institutions (Giddens, 1997: 51).

Like all world religions, Islam is internally diverse. It manifests itself in a vast collection of experiences, practices, and currents. Muslim societies, groups, and individual believers can hold very different, even conflicting positions within its religious and political framework. The Central Asian authorities, however, adhere to a very simplistic dichotomous understanding of Islam that outlived the Soviet epoch. In this view, the state-regulated religious establishments are taken as legitimate and official, whereas everything else is deemed extremist and radical. In reality, Islam has many faces in Central Asia, and Islamic groups and movements are similarly diverse. What unites a spectrum of groups that I refer to as radical Islamic movements is the Islamist ideology 
that calls for a return to the earlier models of Islam. ${ }^{2}$ The radical Islamic groups, themselves, are far from being uniform. They strive for distinctive visions of Islam and espouse different methods of "struggle in the way of God" (Esposito, 2005: 93). Some groups interpret jihad in a purely military sense and resort to violence for influencing politics in the Muslim nations. Others abstain from coercion in transmitting their message, even if it is a radical one.

I begin by marshalling the evidence in support of the ethnic aspect of religious extremism, militancy, and terrorism in Central Asia. ${ }^{3}$ The second section presents explanations of the observed variation. Next, I demonstrate how a greater Islamicization and religious persecution of Uzbeks and Tajiks has contributed to the greater support of radical Islam by these ethnic minorities. The overview of the findings and broader theoretical inferences about the impact of Islamic socialization and framing on receptiveness of Muslims to radical religious calls concludes the study.

\section{Radical Islam in Central Asia: Focus on Ethnicity}

Following the breakup of the Soviet Union, scores of ethnic Uzbeks, Kyrgyz, Tajiks, Turkmen, and Kazakhs were separated from their titular nationalities by the tangled borders of the newly independent states (see Table 1). In the past, the high concentration of Uzbeks, Kyrgyz, and Tajiks in the villages bordering the neighboring republics created a context for inter-ethnic clashes in the multi-ethnic communities of the Central Asian republics. Today, however, many political analysts reckon that the extant ethnic cleavages do not constitute a major threat to the regional stability. The rise of radical Islam has been viewed as the most alarming development in the Central Asian region.

[Table 1 here] 
The problem of religious extremism and terrorism in Central Asia has been associated with activities of the Islamic Movement of Uzbekistan (IMU), Hizb ut-Tahrir, and a number of less known radical Islamic movements, such as Akramiya, Hizb anNusra, and Tablighi Jamaat among others. The IMU is a terrorist organization infamous for a series of terrorist attacks and raids in the Central Asian states, and implicated in ties with the Taliban and al-Qaeda networks. It was established with the aim of toppling President Karimov's secular regime in Uzbekistan, but later expanded its goals in an attempt to create a region-wide Islamic caliphate in Central Asia (Naumkin, 2003). Ideologically speaking, the IMU is a jihadist movement that is not truly Islamist. Its followers have no interest in the transformation of society or converting people to their beliefs. The organization has no political program beyond the conquest of power and the subsequent imposition of their vision of Islam upon people (Khalid, 2007: 16). Another group that has been increasingly active in Central Asia is the Hizb ut-Tahrir al-Islami (The Party of Islamic Liberation). It pursues the same goals as the IMU, but officially eschews violence.

All Central Asian states adopted restrictive religious policies and measures in an attempt to control and manipulate Islam. The bans on unregistered Islamic organizations and persecution of the thousands of Muslims suspected in collaboration with Islamists drove radical Islamic groups underground making their membership numbers and popularity difficult to estimate. The authoritarian nature of Central Asian governments, which often strategically manipulate the discourse on Islamic radicalization, also complicates scholars' efforts at data collection. 
Although, some studies, news articles, and governmental reports assert that radical Islam has made a forceful comeback in the last decade in Central Asia, and its threat to regional security is growing, the reality is more complex. Central Asian states are bastions of moderate and traditional Islam $^{4}$ and the rise of its radical and militant forms has been exaggerated by both the governments and the Islamists. Concerns about the radical Islamic movements persist, however, for a reason, as a number of reputable analyses recorded some growth in the rank-and-file members of radical Islamic groups (see, for example, reports of the International Crisis Group (ICG), a leading non-partisan organization with established presence in Central Asia (ICG, 2003a, 2003b)).

The overthrow of the Taliban regime and the destruction of Al-Qaeda strongholds in Afghanistan severely weakened the IMU. The remnants of this militant organization created a number of splinter groups, such as the Islamic Movement of Turkistan and the Islamic Jihad Union, affiliated to, but not controlled by, the IMU. The former IMU fighters continue to recruit and train volunteers in parts of Central Asia, Pakistan, and Afghanistan, but the numbers of militant Islamists are probably much smaller than figures declared by the governments of Central Asian states. After the last wave of terrorist violence in March 2004 in Uzbekistan, the focus of international attention has shifted to nonmilitant Islamic groups, such as Hizb ut-Tahrir, whose public support has been rapidly spreading across the region. ${ }^{5}$

The first records of Hizb ut-Tahrir's activities in Uzbekistan appeared in the mid1990s. By 1999, the movement attracted between 6,500 and 7,000 followers, and the membership increased to 15,000 by 2003 according to the estimate of a well-informed Tashkent scholar (ICG, 2003a: 17). In Kyrgyzstan, where the group appeared in 1997, the 
membership was between 1,000 and 2,000 in early 2000 s, and reached as many as 7,000 to 8,000 member by 2009 (ICG, 2009).In Tajikistan, Hizb ut-Tahrir recruited more than 1,000 members in the early 2000s (ICG, 2003a: 18), and reports of its activities in southern Kazakhstan have appeared around this time as well. There, observers estimate the movement's membership in low hundreds. Yet, the recent reports of the Kazakh security service allege unprecedented growth in the activities of other radical Islamic groups. In 2003, Kazakh police seized over 1,000 leaflets with radical Islamic calls. By 2004, the number of seized pamphlets increased to 11,000 , and a cell of the Jamaat Mujahedin of Central Asia with alleged ties to al-Qaeda was dismantled the same year in Kazakhstan (Shpekbaev, 2005).

The Central Asian governments have been threatened with the growing popularity of radical Islamic groups and the recurrence of raids by Islamic militants, but have been deliberately inattentive to the ethnic aspect of religious extremism, militancy, and terrorism in their states. Yet, in each of the Central Asian republics, Islamists have been able to gain more support among Uzbeks and Tajiks, than among the indigenous Kyrgyz, Kazakh, and Turkmen populations.

After the raids of Islamic militants on Kyrgyzstan in the summer of 1999, the IMU established a social base in the Ferghana valley, a densely populated and ethnically mainly Uzbek territory divided politically between Uzbekistan, Kyrgyzstan, and Tajikistan. The majority of the IMU recruits from the Kyrgyz population have been Uzbek (Amnesty International, 2005; Human Rights Watch, 2002; Kimmage, 2006). Official documents released by the Kyrgyz National Security Service contain references to the Uzbek ethnicity of Islamists. 
The membership in non-militant Islamic groups operating in Kyrgyzstan has also been overwhelmingly Uzbek (ICG, 2003a; Rotar, 2006). Hizb ut-Hahrir, for example, has been very active in the Ferghana Valley as well as in the southern Osh, Batken, and JalalAbad provinces of Kyrgyzstan where the Uzbek minority is concentrated (Botobekov, 2001: 132). The Kyrgyz security sources claim that Uzbeks constitute up to 90 percent of the membership of Hizb ut-Hahrir, while ethnic Kyrgyz make up three to four percent (ICG, 2003a: 18). In fact, almost all members of Hizb ut-Tahrir arrested in Kyrgyzstan have been ethnic Uzbeks, and nearly all Islamic clerics implicated in collaboration with banned religious groups have been of Uzbek origin (Karagiannis, 2005, 141).

Since the end of the civil war in 1997, Tajikistan has experienced a surge of militant attacks most of which were blamed on the IMU. The Tajik government claims that the IMU operatives are ethnic Uzbeks who crossed into Tajikistan from Uzbekistan fleeing prosecution by the Uzbek government in the aftermath of the 1999 terrorist bombings in Tashkent (Kimmage, 2006; Naumkin, 2005: 166). Hizb ut-Tahrir in Tajikistan is also heavily ethnic Uzbek with the majority of followers concentrated in the northern Sugd (former Leninabad) province, where Tajikistan's Uzbek minority is primarily based. Some ethnic Tajiks have also been drawn to the group. However, the movement's core constituency remains predominantly Uzbek (ICG, 2004; Naumkin, 2005: 166).

The growing radicalization of Islam in Kazakhstan has also occurred mostly among ethnic Uzbeks. The radical Hizb ut-Tahrir has been active in the southern Shymkent oblast bordering Uzbekistan. The Kazakh authorities deny the existence of home-grown terrorists and religious extremists maintaining that Islamists infiltrated 
Omelicheva, Mariya Y. Ethnic Dimension of Religious Extremism and Terrorism in Central Asia, International Political Science Review, 2010 31(2): 167-186. Publisher's Official Version: <http://dx.doi.org/10.1177/0192512110364738>.

Open Access Version: <http://kuscholarworks.ku.edu/dspace/>.

Kazakhstan's southern regions from Uzbekistan, Tajikistan, and Russia. Public reports released by the Kazakh security services and court rulings recounted by the international human rights groups also refer to the Uzbek fellowship of the radical Islamic groups in Kazakhstan.

In Uzbekistan, as in other Central Asian states, Hizb ut-Tahrir derives its largest following from ethnic Uzbeks. The cities of Namangan, Kasansai, and Andijan located in the Uzbek part of the Ferghana valley are considered to be the stronghold of radical Islam in Central Asia. However, radical Islamic groups also enjoy wide support among ethnic Tajiks in Uzbekistan, according to findings of the field researchers and the background information on the arrested Hizb ut-Tahrir members (Ahmedova and Leitich, 2001).

Little information about radical Islamic groups in Turkmenistan leaks to the outside world due to the total secrecy of the regime established by late President Niyazov. Some analysts contend that no Islamists could escape the reach of the powerful repressive apparatus of the Turkmen government. Other regional specialists maintain that radical Islamic groups operate underground in Turkmenistan. Hizb ut-Tahrir, for example, has been active in the Turkmen prisons (ICG, 2003a). Some of the moves of late President Niyazov serve as evidence of Turkmenbashi's growing concerns with the rise of radical Islam in the state, and fear of radicalization of Turkmenistan's Uzbek population. In 2003, Niyazov deposed and imprisoned the Chief Mufti, Nasrullah ibn Ibadullah. Ibadullah is the ethnic Uzbek who had led Turkmenistan's Muslims for more than ten years (Corley, 2004; Institute for War and Peace Reporting, 2005). Following Ibadullah's ousting from the post, many prominent Muslim Uzbek leaders were arrested and sentenced to different terms. The authorities have unseated ethnic Uzbek imams and 
replaced them with ethnic Turkmen even in the areas predominantly populated by the Uzbek minority (Rotar, 2004c). The government reportedly ordered the forced relocation of some Uzbeks living along the common Uzbek-Turkmen border. Turkmen Muslims were banned from receiving religious education in Uzbekistan, and the government shut down Turkmenistan's only university department of Muslim theology.

In the closed political and media environment, there has been no discussion of the motives of the Turkmen government for taking a harder line against ethnic Uzbeks in Turkmenistan. Central Asian analysts speculate that Ashgabat's attack on Uzbeks is an indirect consequence of turbulence in neighboring Uzbekistan, and fear of the rise of proIslamic sentiments in the communities of Turkmenistan's Uzbek Muslims.

\section{Rallying for Radical Islam: Theory of Support and Joining}

The recent tide of extremist and militant forms of Islam around the globe has reinvigorated research in radical Islamic groups. The majority of studies have drawn on the theories of social movements to explain the rise of the Islamist groups (Bayat, 2005; Karagiannis, 2005; Meijer, 2005; Wiktorowicz, 2002, 2004b). Some scholars emphasize the primacy of socio-economic conditions and psychological roots of Islamic activism. According to this reasoning, various socio-economic and political pressures breed public discontent, thus precipitating collective action (for a succinct review see Naumkin, 2005: 21-31; Wiktorowicz, 2004a: 3). Other researchers shift their focus on the rational facility of people who weigh pros and cons of joining Islamist groups. From this perspective, support for Islamic movements is a rational decision inspired by various selected incentives provided to people by radical Islamic groups (Wiktorowicz, 2004a: 4-5). With the proliferation of interest in the role of ideas, identities, culture, and cognition, some 
researchers turned to the analysis of frames that mediate the impact of various background conditions on people's decisions. Frames render specific understanding of solutions to individuals' grievances, and provide the rationale needed to encourage support for radical Islamic groups (Benford and Snow, 2000; Chandler, 2005).

Socio-economic and political difficulties are ubiquitous across Central Asia (see Table 2). High unemployment rates, poverty, and shrinking welfare coupled with the lack of opportunities and poor governance can serve as a breeding ground for radical Islamic movements. Yet, the socio-economic and political distress is neither necessary nor sufficient condition for explaining the spread of radical Islam. Radical Islamic groups can emerge under conditions of social dislocation and economic stagnation. Islamists can also appear in the societies that are relatively developed socio-economically (Hafez, 2003; Naumkin, 2005: 22). There has been lack of evidence that convincingly demonstrates the existence of a relationship between various indicators of the levels of development and political depravation, on one side, and the rise of radical Islam and terrorism, on the other (see, for example, Hafez, 2003; Krueger and Maleckova, 2003; Piazza, 2006).

The ranks of Islamist movements in Central Asia have been drawn from the relatively well-off and educated urban populations as well as from among the poorer segments of the Central Asian societies. Kyrgyzstan's and Turkmenistan's development indicators have been consistently below those in Uzbekistan, but Muslims in these republics have been less prone to religious extremism than in Uzbekistan. The latter has become a hotbed of the radical Islamic movements. However, other Central Asian states, particularly Tajikistan, have seen a steeper decline in living standards. In Kazakhstan, 
too, the patterns of poverty distribution do not square well with the patterns characterizing the spread of radical Islam (see Table 2) (World Bank, 2004).

[Table 2 here]

There is no hard evidence that the provision of monetary rewards by Islamists is the primary reason for joining. Even if the recruits receive payments, it is very unlikely that many would risk their personal security and freedom for small financial benefits (ICG, 2003b). The Uzbek and Tajik minorities hold acute social, political, and economic grievances over persistent discrimination. However, the mere existence of deprivations is not enough to cause them join the radical Islamic groups.

Why, on the background of progressive impoverishment of the population and increasingly undemocratic nature of all Central Asian regimes, more Uzbeks and Tajiks have been drawn to radical Islam than representatives of other ethnic groups in the region? It is my contention that, ceteris paribus, two related factors - the greater Islamicization of these ethnic groups and their religious persecution - explain minorities' support of the radical Islamic groups. The impact of the identified factors can be best understood in the context of the social movement theory that provides a unifying framework of conditions that are connected to mobilization processes, including structures of political opportunities, resource mobilization, and framing.

To induce participation in the high risk activities of radical Islamic groups, individuals have to be persuaded that the cause they choose to support is worth the perils and costs of involvement (Wiktorowicz, 2004a: 7). The ability of radical Islamic groups to convince individuals to join depends not only on the structure of political opportunities 
and resource availability, but also their ability to frame their appeals in such a way that they resonate with the prospective members (Chandler, 2005).

Poverty, discrimination, and other kinds of distress are important in that they compel people to seek out and embrace alternative views on the nature and causes of their problems. In the absence of other viable means of expressing dissent and affecting change, people can turn to radical Islamic groups that provide easy answers and simple solutions to social and individual concerns. Whether the movement's message will reach the targeted audience depends on the people's receptiveness to broad religious declarations. Those individuals who have had prior Islamic experiences are typically more receptive to the movement's religious appeals (Wiktorowicz, 2004a).

The stronger an individual's identity is tied to Islam, the greater the likelihood that he or she will seek further exposure to Islamic teachings and become involved in the discussion and exchange of ideas over religious meanings and alternative ways of viewing the world (Wiktorowicz, 2004a: 8). The ability of an Islamic group to frame this debate in such a way that it resonates with the listeners' experiences of discrimination and deprivation, as well as their Muslim identity, will determine success of its recruiting efforts. Once the frame alignment is achieved, i.e., individuals accept the group's interpretations and solutions to the pending problems, they become more committed to its cause through participation in a variety of micro- and macro-mobilization activities, which can include study groups, independent readings, one-on-one discussions of Islam, as well various types of non-violent and violent action.

Repression by the state will affect the structure of political opportunities of the Islamist groups. Yet, the nature of the relationship between state sanctions and dissent 
has been one of the most perplexing questions (see, for example, Lichbach, 1987; Moore, 1998). Some analysts claim that repressive measures inhibit mobilization efforts by increasing the costs of participation in various forms of dissent (Snyder and Tilly, 1972; Muller and Weede, 1990). For others, repression simply encourages more violent action (Khawaija, 1993).

Recent studies of Islamist movements support both conclusions. Preemptive and targeted state repression may reduce political violence and diminish the level of popular support for Islamist groups (Hafez, 2003: 72-76). However, as the level of violence employed by the state escalates to the points that it becomes indiscriminate and reactive, violent dissent by the radical Islamic groups will increase. Blanket repression will serve as a catalyst for increased public support of the Islamist opposition. Hafez (2003: xv) in his comparative studies of Islamic movements in Algeria and Egypt, as well as in Jordan, Pakistan, Tunisia, Kashmir, the Southern Philippines, Chechnya, and Tajikistan, found that Muslims of these states turned to violent means in response to indiscriminate repressive measures employed by exclusionary governments against their citizens during the period of mass mobilization. State repression triggered "a dynamic of radicalization characterized by exclusive rebel organizations that isolate Islamists from their broader society and foster antisystem ideologies that frame the potentially healthy competition between secularism and Islamism as a moral struggle between faith and impiety" (Hafez, 2003: xv). State violence provides Islamists with an additional avenue for using Islam to legitimate the expression of both secular and religious concerns, and frame their teachings in such a way that they resonate with the individuals' experiences of repression. 
The following sections of the paper demonstrate how the historical differences in the introduction and practice of Islam in the societies of Central Asia translated in the varied role of Islamic faith among Uzbeks, Tajiks, Kyrgyz, Kazakh, and Turkmen. The greater Islamicization of Uzbeks and Tajiks increased susceptibility of these ethnic groups to Islamists' religious teachings. The stronger religious identification exposed the devout Uzbek and Tajik Muslims to increased state persecution. In the absence of functioning interest-based organizations, or other institutions for channeling the minorities' frustration and dissent, Uzbeks and Tajiks have used radical Islamic groups for expressing their grievances about social and political constraints and religious persecution.

\section{Patterns of Islamicization in Central Asia and Its Impact on Radicalization of}

\section{Muslim Communities}

The Islamicization of Central Asia began in the second part of $7^{\text {th }}$ century. It was a protracted and uneven process affected by rich pre-Islamic traditions, sedentary and nomadic cultures, and geopolitical situation in the region. Different patterns of dissemination and practice of Islam unfolded in two parts of Central Asia, namely, Mawarannahr (also known as Transoxiana), the territory between the Amy Darya and the Syr Darya rivers, and Turkistan occupying vast lands to the north-east of Mawarannahr. The territory of Mawarannahr was populated by the people of Iranian origin and some Turkic tribes. It is in these early settlements of farmers and traders that the Arab armies brought new religion, Islam, in $7-8^{\text {th }}$ centuries. The sedentariness of the ancestors of modern Tajiks and Uzbeks was an important factor in the early adoption of Islam and close observance of Islamic laws and prohibitions in Transoxiana. Islam is a religion of 
settled people, since it requires a developed urban infrastructure for institutionalized Muslim practices. The natives of Mawarannahr built mosques and madrasas in their villages. The towns of Bukhara, Samarkand, and Khiva developed into the major cultural and religious centers of the Muslim world.

The wide steppes of Turkistan populated with itinerant tribes provided less fertile soil for Islam, and the nomadic culture was more difficult to convert. Although the present-day Turkmen had been in the Islamic orbit since the $10^{\text {th }}$ century, most of the Kazakhs and Kyrgyz were converted to the Sunni branch of Islam by the end of $19^{\text {th }}$ century (Sagdeev, 2000: 8). Adopting Islam, the nomads adjusted the basic tenets of the new religion to their own "cosmological precepts," socio-cultural values, and indigenous worldviews informed by the nomadic and tribal cultures (Allsen, 1997). The Islamic practices of the nomadic societies have been intricately entwined with pre-Islamic pagan traditions and adat, a common law prevalent in the steppe (Klyashtorny and Sultanov, 1992: 150; Zhusupov, 2001). For that reason, Kazakhs, Kyrgyz, and Turkmen have been known as nominal Muslims for they have never observed Islamic prohibitions and laws very closely.

Thus, historically Islam played a more superficial and varied role on the territories of Kyrgyzstan, Kazakhstan, and Turkmenistan formally inhabited by nomads than in the regions of the sedentary Uzbek and Tajik Muslims. The policies of Tsarist and Soviet Russia had strengthened this pattern. During the colonial period the tsarist administration made an important distinction between the nomadic and sedentary populations based on the role of Islam (Khalid, 2007: 33). In the nomadic societies, where Islam was viewed as a small piece of the mosaic of pre-Islamic traditions, the Russian state promoted 
Russification and supported the rule and practices of the indigenous law, adat. The sedentary populations associated with real Islam were to be governed by Shari'a. As a result, many Islamic institutions as well as educational and cultural spheres were left intact in both Turkistan and Transoxiana. In the sedentary regions local judicial systems based on the Islamic law provided a space for the growing influence of the ulema, the most educated Muslim scholars, and evolution of Islamic teachings (Khalid, 2007: 38).

The Bolshevik government nearly decimated the main bastions of Islam. The new regime abolished religious educational institutions, banned the Shari'a courts, harassed Islamic clergy, and closed the mosques (Ro'i, 2000: 714). Although, the Soviet assault on the Islamic way of life was ferocious, the destruction of the main features of pre-1917 Islam was not total. The Soviet purges drove Muslim ulema underground that helped to preserve the pre-soviet elements of Islam (Sagdeev, 2000: 9). The faith also stayed alive in the people's consciousness and social practices, particularly in the most remote areas of Tajikistan and Uzbekistan, where significant number of mosques had survived state repression. Toward the end of the Second World War the Stalin regime had softened its stance on religion. In 1943, the government allowed the establishment of the Spiritual Administration of the Muslims of Central Asia and Kazakhstan and permitted religious observance and education without persecution. The survived madrasas began offering theological education for a limited number of students, and some of the Soviet Muslims were allowed to travel abroad (Khalid, 2007: 78).

When the Soviet government had loosened its grip on religion, Islam made a vigorous comeback. Yet, the Islamic revival in Central Asia was very uneven. The traditional centers of Islamic activity - Tajikistan and Uzbekistan, as well as the northern 
parts of Kazakhstan and Kyrgyzstan inhabited by Uzbeks, Uighurs, and Dungans became the epicenters of the resurfaced Islamic tradition (see, for example, Ro'i, 2000: 460). In late 1950s, 202 of 495 functioning mosques in the Soviet Union were in Uzbekistan, 18 in Kazakhstan, and only 4 in Turkmenistan (Ro'i, 2000: 62). The urge to open and register mosques in Kazakhstan and Kyrgyzstan was much less than in the historically sedentary areas populated by Uzbeks and Tajiks (Ro'i, 2000: 185). The latter two ethnic groups had a disproportionally high representation among the Islamic clergy.

After the establishment of the Spiritual Administration of the Muslims of Central Asia and Kazakhstan some reformist ulema distanced themselves from the official clergy controlled by the Soviet regime. They took self-consciously conservative positions on issues of Islamic tradition and called for re-Islamicization of Uzbekistan and Tajikistan. During the Brezhnev era, some of these Muslim clerics began teaching lessons to selected students in the underground religious circles in Tajikistan and Uzbekistan (Khalid, 2007: 114). Later, these study groups evolved into politicized groupings of Islamic devotees, some of which identifying with Wahhabism (Miloslavski, 2001: 82). The other three "stans" - Kazakhstan, Kyrgyzstan, and Turkmenistan - saw very little of this kind of religious activity (Khalid, 2007: 114).

In addition, after independence, Muslim activists from Turkey, Pakistan, Saudi Arabia, Afghanistan, and other Muslim states inundated Central Asia (Rashid, 2001). The Uzbek and Tajik communities attracted a bulk of these Muslim "missionaries" due to the previous contacts of the Uzbek and Tajik ulema with the outside religious world and concentration of the Islamic infrastructure in these Central Asian republics. The Uzbek and Tajik communities received a significant inflow of human and financial resources 
utilized for the construction of new mosques and madrasas. There were 6000 mosques built in Uzbekistan in 1993, compared to 300 in 1989 (Yerekesheva, 2004: 584). In Tajikistan, 2000 new mosques were opened during 1989-91. Kyrgyzstan, on the other hand, had only 1000 mosques by 1995 with the majority of those mosques located in southern Kyrgyzstan (Karagiannis, 2005: 143; Yerekesheva, 2004: 584). In Kazakhstan, there were 1402 mosques built toward the late 1990s (Yerekesheva 2004: 585).

Thus, in the communities of the Tajik and Uzbek Muslims, social and political conditions, the presence of influential Islamic clergy, developed religious infrastructure and intellectual environment were ripe for the emergence of radical Islam. The societies of the indigenous Kyrgyz, Kazakh, and Turkmen Muslims lacked these important preconditions. Furthermore, the return to Islam took a somewhat different form in Kazakhstan and Kyrgyzstan, the two republics that had been subjected to intense Russification as a consequence of the influx of Russians. There, the public authorities and some ordinary people have been ready to embrace Islam as a part of the greater ethnic idea, and to assert a local identity against the Russians who had long overshadowed the local cultural life (Khalid, 2007: 119).

In a nutshell, the differences in the prior socialization experiences with Islam exposed Uzbek and Tajik Muslims to radical Islamic teachings. The "cognitive opening" prompted by the socio-economic and political crises made them more receptive to radical Islamic calls that are typically framed so as to resonate with people's personal and social problems. The extensive social and religious networks and a system of religious institutions have also enabled the outreach by Islamists. 
Hizb ut-Tahrir in Central Asia has been particularly successful in utilizing its ideology in recruiting and mobilizing efforts. The movement has a long history of legal and underground work, and considerable experiences in propagandizing. The movement's pundits prepared succinct descriptions of the religious, political, and economic foundations of an idealized Muslim state using selective interpretation of Islamic theology and history. Hizb ut-Tahrir developed theological arguments grounded in the passages from the Qur'an to vilify the governing regimes and to defend the promulgated religious ideals (Badadzhanov, 2001; Karagiannis, 2005: 144).

The emissaries of Hizb ut-Tahrir have typically used the existing social and religious networks for launching new relationships with the congregation. The mosques and seminaries have also served as a convenient recruitment platform. After listening to the imam's sermon, Muslims may stay in the mosque for discussion of some aspects of the religion. Questions about Islam or people's individual concerns can be raised and discussed in the circles of friends or other social groups. It is in these guided conversations, as well as through leaflets and messages on the Internet, that the members of Islamist movements employ their views on Islam for legitimizing the listeners' secular and religious frustrations and questions, and attempt to relate their teachings to people's experiences and concerns.

The Islamists rarely offer concrete explanations to problems, particularly in the social and economic domains. Instead, they invoke some "absolute" values and rely on effective emotional appeals. Pleas for equality and social justice, for example, have traditionally permeated the rhetoric of Islamists. In Central Asia, Hizb ut-Tahrir has attempted to match these appeals to the societies' unique contexts by introducing some 
elements of a socioeconomic and political program into their doctrine. In Tajikistan, that is still in recovery from the civil war carnage, Hizb ut-Tahrir has been stressing nonviolence as a method of struggle for their Islamic ideas (Naumkin, 2005: 161). In the Uzbek communities, Hizb ut-Tahrir has promoted a vision of a borderless and nationless Islamic state. For many Uzbeks, who feel dissatisfied with their post-Communist status and isolated from their families in Uzbekistan, these views have been very attractive (Karagiannis, 2005: 142).

The simplicity of the Islamists' teachings makes them very effective. The Islamist groups advocate reconstruction of an ideal society or an Islamic state, in which socioeconomic problems are nonexistent or can be resolved by implementing the principles of Shari'a law. This religious message appears convincing in the region of growing inequality, rampant corruption, and rigid authoritarianism. Particularly those who have been socialized in the Islamic context are more predisposed to embrace and defend these views.

\section{Religious Persecution of Ethnic Minorities}

Because of the greater spread of radical Islam in the communities of Uzbek and Tajik Muslims and tight association of Islamism with these ethnic groups, nearly all measures aimed at combating terrorism and religious extremism in Central Asia have impinged on the Uzbeks and Tajiks. In Kyrgyzstan, for example, following the IMU raids in 1999, hundreds of ethnic Uzbeks, Tajiks, and Afghans were rounded up on suspicion of collaboration with the Uzbek and Tajik fighters (Human Rights Watch, 1999). In a series of counterterrorism operations that followed the incursions, Kyrgyzstan's security forces raided Uzbek communities, and some Uzbek settlers were detained without a warrant for 
arrest (Azimov, 2006). In 2006, the Kyrgyz authorities conducted more counterterrorism sweeps killing some people and arresting dozens of alleged Islamic radicals, mostly ethnic Uzbeks (Firdavsi, 2006).

The Kyrgyz law-enforcement agencies have persecuted several Uzbek imams for their supposed involvement in radical Islamic groups, and tolerated occasional abductions of Islamic activists by the Uzbek secret service. In the fall of 2006, following the government's killing of a prominent ethnic Uzbek religious leader, Rafig Qori Kamuluddin, implicated in ties with the IMU, the security services of Kyrgyzstan developed a special plan for strengthening state control of the republic's Islamic clergy. The plan envisages, among other things, extensive monitoring of the Kyrgyz citizens of Uzbek and Uighur origin who have lived in the south of the republic, and those individuals who have arrived from Uzbekistan (Djuraev, 2006).

For a long time, there has been a deep-seated animosity between Tajiks and Uzbeks $^{6}$.which translated into mutual distrust and a tenuous relationship between the Tajik and Uzbek governments (Torbakov, 2001). The civil war in Tajikistan reinvigorated this historical rivalry between Tajikistan and Uzbekistan. The Tajik government accused its Uzbek counterpart of supporting political unrest and separatist aspirations in Tajikistan's Leninabad oblast (Human Rights Watch, 1998). This most "Uzbekified" part of Tajikistan has traditionally maintained strong political, economic, and cultural ties with Tashkent. Dushanbe authorities also insisted that Mahmud Khudorberdiyev, the rebellious Uzbek colonel, received some assistance from Uzbekistan (Parker and Branch, 2000). Following the 1997 uprising led by the renegade colonel, the government of Tajikistan took revenge on the Uzbek population. After the government's 
detachments drove off the rebel's brigade, the troops looted the ethnic Uzbeks' homes to punish them for the alleged support of the commander (Open Society Institute, 1998).

For Dushanbe’s authorities, Hizb ut-Tahrir has been an "Uzbek movement" (ICG, 2003b). Naturally, the map of geography of arrests of the alleged members of Hizb utTahrir has corresponded to areas with high concentration of the ethnic Uzbeks (ICG, 2003b). The followers of Hizb ut-Tahrir have endured unfair trials and have been abused in detention, and the relatives of the movement's supporters have been harassed by the government of Tajikistan (Abdullaev, 2004).

Uzbekistan's government has traditionally used a decidedly authoritarian approach toward the supporters of Islamist movements. Tashkent's authorities have also been known for their persecution of Muslims of the Tajik descent. The latter have been portrayed as the Islamists' sympathizers, and the "terrorist" image has served as a pretext for harassing the ethnic Tajiks (Amirkulov, 2005). In 2000, the Uzbek security services evicted several hundreds of Tajik families from villages in southern Sukhandrya region with the alleged purpose of clearing the area of the IMU troops. The settlers were transferred to a wilderness in the southern Sherabad district, while the Uzbek air force destroyed their homes. About 70 ethnic Tajiks from Dara-i-Nihon, including 21 teachers, were charged with complicity in terrorism. The defendants confessed to the alleged crimes under duress and were imprisoned for between eight and eighteen years (U.S. Department of State. Bureau of Democracy, Human Rights, and Labor, 2001).

Regional experts have noted the impact of Tashkent's indiscriminate repression on the radicalization of Muslim believers and spread of radical Islam in Uzbekistan. For instance, most of the female suicide bombers who took part in the 1999 explosions in 
Tashkent were the family members of the prosecuted Uzbek Muslims, and their violence was a sign of protest against the harsh policies of the government of Uzbekistan (Naumkin, 2005: 116). The deepening resentment of the Tajik population has also matched the growing influence of Hizb ut-Tahrir. The movement enjoys wide support among Uzbekistan's Tajiks who have become discontent with persistent oppression, growing poverty and unemployment, and the heightened border regime with Tajikistan introduced by Uzbekistan.

In Kazakhstan, fewer ethnic Uzbeks have been drawn to Islamist movements than in the neighboring states. This stands in the marked contrast with the situation in southern Kyrgyzstan where virtually all Kyrgyz members of Hizb ut-Tahrir are ethnic Uzbeks. One reason for this discrepancy is Kazakhstan's ethnic composition. There are fewer Uzbeks in Kazakhstan than in Kyrgyzstan (3.7\% against $14.2 \%$ of the total population), and Russians constitute the largest non-titular nationality. Until 2005, the lawenforcement agencies of Kazakhstan had no legal ground for prosecuting Islamists, and activities of Hizb ut-Tahrir were not officially banned (ICG, 2003b). Kazakhstan's more liberal religious policy and fewer constraints on the rights of the minority groups have been an important barrier to mobilization of Uzbek Muslims.

The situation may change, however. In 2004, several ethnic Uzbeks from the Shymkent oblast of Kazakhstan were implicated in a series of Tashkent suicide bombings in Uzbekistan. Following these attacks, Kazakhstan's government intensified measures against radical Islamic groups, and tightened control over religious practices, particularly in the south of the country. Uzbek imams in southern Kazakhstan came under the renewed pressure of subordination to the state-backed Spiritual Administration of 
Muslims in Kazakhstan (Ponomarev and Jukeyeva, 2002). Instituted in 1990, the Administration initiated the displacement of ethnic Uzbeks from their positions as imams, and today most of the mosques in the south of Kazakhstan are headed by ethnic Kazakhs. This situation is upsetting to local Uzbeks who choose to commute to Uzbek villages for important prayers because, in their view, Kazakh religious leaders possess less profound theological knowledge than the Uzbek clergy (Rotar, 2004a, 2004b). Since 2004, all imams in the South of Kazakhstan have had to pass a compulsory re-attestation (Rotar, 2005). In a sign of the growing discontent with religious policies of the Kazakh administration, Muslims of Kazakhstan staged an unauthorized demonstration in Almaty in January 2005. Following this event, the Kazakh security forces carried out a stream of arrests of the supposed members of Hizb ut-Tahrir who were accused of staging the unauthorized protest. The Kazakh authorities began closely monitoring the Uzbekpopulated areas of Kazakhstan. The arrests of the members of banned organizations and the seizure of Islamists' literature have become more pronounced in the republic's south (Mukhametrakhimova, 2006).

\section{Conclusion}

The goals of this research were to demonstrate the differences in the ethnic make-up of radical Islamic movements in Central Asia as well as to explain the observed variation in the extent of support of radical Islamic groups by various ethnic groups. Although, representatives of all ethnic backgrounds have been drawn to radical Islamic groups, Islamists' proselytizing efforts have been particularly effective among ethnic Uzbeks in southern Kyrgyzstan and Kazakhstan, as well as among Uzbeks in Tajikistan and Tajiks 
in Uzbekistan. The study attributed this success to the greater Islamicization of Uzbeks and Tajiks, and religious persecution of the ethnic minorities.

The rise of Islam in the communities of Uzbek and Tajik Muslims has demonstrated the importance of Muslim identity, ideology, and framing in garnering their support. The failure of secular democratic resistance in Central Asia is linked to the fact that democracy, as defined in the West, is an alien notion to many Central Asians who have been less inclined to fight for the democratic ideals and ideology imposed from abroad. The Central Asian authorities have employed the rhetoric of democracy for boosting their international and domestic image, but repeatedly stated that they would promote their own "special" types of democracy informed by specific circumstances of their countries' development.

Historical experiences from the Soviet and colonial past have left their marks on the internal developments of the Central Asian republics. The legacy of the communist rule has been a big handicap for establishing a democratic rule. The resurgence of Islam, a potent political and cultural force, has stifled other nationalist trends and establishment of democratic institutions (Hunter, 2001). The Central Asian authorities eagerly embraced Islam, if only its official permutation, and used the Islamic creed to bolster the legitimacy of regimes. The advocacy of democratic ideas and activities of democratic organizations were severely curtailed in Uzbekistan and Turkmenistan. In Kazakhstan and Kyrgyzstan, where democratic movements received more popular support, they were much weaker than movements of civil rights and political freedoms active in Eastern and Central Europe. 
This study found that Islamists' efforts were less successful in the communities of the ethnic Kyrgyz. Part of the reason comes from the fact that their Islamic identity is relatively new and not well-defined. The religious beliefs of the Kyrgyz Muslims have been rather eclectic. Since recently, however, some noted the growing religious selfconsciousness and religious seeking among the ethnic Kyrgyz. The soaring grassroots interest in Islam combined with the worsening economic and political situation in the country reopened a window of opportunity for radical Islamic groups. Hizb ut-Tahrir, for example, has adjusted its framing and proselytizing tactics there. Traditionally, it focused on vilifying the rule of president Karimov in Uzbekistan. Today, it calls for the toppling of the Kyrgyz secular government. More of Hizb ut-Tahrir's literature is published in Kyrgyz with some leaflets condemning the policies of Kyrgyzstan's "infidel" and corrupted leaders.

Since the rise of radical Islam is, to a large extent, about religious beliefs and ideas, it should be responded to at this level as well. The state-imposed strictures on media freedom and religious controls are encouraging a turn to Islamism, which continues to fill in the informational and ideological vacuum created after the Soviet demise. The new legislative measures adopted by each of the Central Asian states with the aim of combating terrorism and religious extremism repel local and national media from any serious discussion or in-depth coverage of religious topics. Instead of stifling religious freedom and limiting discussion of the issues of faith, the Central Asian governments need to promote extensive religious and spiritual education, encourage dialogue within Islam, and support the expansion of critical coverage of religious issues by broadcasting organizations. One of the most effective strategies for coping with the 
Omelicheva, Mariya Y. Ethnic Dimension of Religious Extremism and Terrorism in Central Asia, International Political Science Review, 2010 31(2): 167-186. Publisher's Official Version: <http://dx.doi.org/10.1177/0192512110364738>.

Open Access Version: <http://kuscholarworks.ku.edu/dspace/>.

growth of radical Islamic movements and politization of Islam is through enlisting the assistance of competent theologians at the local and national levels. For this to happen, the official Islamic clergy should expand its educational, ideological, and informational work with the population to improve its reputation, increase trust, and perception of religious knowledge.

The stronger Islamic identification of Uzbeks and Tajiks not only facilitated their mobilization by radical Islamic movements, but also exacerbated ethnic and religious tensions in the ethnically-mixed communities of the Central Asian states. There has long been a latent rivalry among the Central Asian ethnos regarding their "Muslimness" (Lubin and Rubin, 1999). The settled Uzbeks believe that they are better Muslims than Kyrgyz and Kazakhs, whereas Tajiks contend that they are the "real Muslims" of Central Asia, as opposed to peoples of the Turkic origin (Ahmedova and Leitich, 2001). This competition around the degree of religiosity of different ethnic groups gave rise to a widespread practice of constructing ethnically separate mosques and religious schools for Uzbeks, Kyrgyz, and other Muslims. The governments' clampdown on the Uzbek and Tajik believers has further complicated relations of ethnic minorities with authorities of the Central Asian states and reinforced the dividing lines between titular nationalities and other ethnicities. The correspondence of the growing inter-ethnic tensions with activities of Islamists has been a deeply troubling development, particularly in Kyrgyzstan. The south of the Kyrgyz republic has seen an alarming number of small-scale clashes between the indigenous population, and the Uzbeks and Tajiks (Khamidov, 2002). The local authorities have recorded a number of violent attacks with the representatives of other faiths (Rotar, 2006). Some public officials expressed concerns that in the future Islamists 
will attempt to foment an inter-ethnic conflict in the Ferghana Valley to destabilize the situation in the region and weaken the governing regimes.

The evidence examined in the study suggests that the strategy of governmental reprisals has been ineffective in eliminating or reducing the spread of radical Islam. The governments' repression served as a temporal deterrent that drove some Islamists underground. Yet, over time, vigorous region-wide crackdown on radical Islam resulted in more militancy and an increase in the number of religious zealots. Repressive politics toward Muslims practicing their faith outside of religious confines established by the Central Asian states has become yet another in a series of grievances that has radicalized moderate believers, and generated widespread sympathy for the oppressed in the broader population.

To neutralize the threat of radical Islam, the Central Asian governments need to explore alternative paths. The socio-economic and political reforms that will improve people's lives regardless of their ethnic background are necessary conditions for the achievement of social harmony in the Central Asian republics. The governments of the Central Asian states should develop and enact measures that will assist the ruling elites in gaining support of moderate Islamic groups and those Islamists who are open to a dialogue with state officials. To thwart radical groups' attempts at gaining large-scale support among Uzbeks and Tajiks, the governments have to foster initiatives designed to accommodate the interests of these ethnic groups, and integrate the ethnic minorities into the Central Asian states and societies. Repressive tactics against minority groups are counterproductive and should be avoided at any cost. The use of counterterrorist and counter-extremist operations as a pretext for suppressing minorities' campaign against 
Omelicheva, Mariya Y. Ethnic Dimension of Religious Extremism and Terrorism in Central Asia, International Political Science Review, 2010 31(2): 167-186. Publisher's Official Version: <http://dx.doi.org/10.1177/0192512110364738>.

Open Access Version: <http://kuscholarworks.ku.edu/dspace/>.

various forms of ethnic discrimination is an unacceptable move that will stir up hostility toward the governing regimes rather than lay foundation for stability in the region. 


\section{Notes}

${ }^{1}$ A notable exception is Oliver Roy (2000) and Dr. Emmanuel Karagiannis. The latter claims that Hizb ut-Tahrir is essentially an Uzbek phenomenon, particularly in southern Kyrgyzstan and Kazakhstan.

2 There are many conceptual disagreements on the best terminology and precise meaning of different strands and manifestations of Islam. For discussion of some basic concepts and terms in Islam, including but not limited to "Islamic fundamentalism", "Salafism", “Islamism”, "jihadism” and others, (see Khalid, 2007; Naumkin, 2005, among others).

${ }^{3}$ Data on detentions, arrests, trials, and thwarted terrorist attempts in the republics of Central Asia was retrieved from a larger dataset on states' responses to terrorism that the author created using event data collection techniques. The primary source of information for coding events on various dimensions of states' responses to terrorism was the wire reports downloaded using the LexisNexis ${ }^{\circledR}$ Academic newswire service. To triangulate conclusions from the event data analysis, I conducted a series of unstructured interviews with political analysts, representatives of human rights groups, and ordinary practitioners of Islam in Kyrgyzstan. I also systematically examined reports (in English and Russian) published by the reputable analytical sources that monitor political and security trends in Central Asia, and examined evidence from ethnographic and field studies of radical Islamic groups.

${ }^{4}$ The majority of Central Asians belong to Hanafi Sunnism, the most tolerant and liberal school of thought of Sunni Islam. According to the CIS World Fact Book (2008), in Kyrgyzstan, 75 percent of the population professes Islam; in Kazakhstan - 45 percent; in 
Tajikistan and Turkmenistan - 85 and 88 percent respectively; and in Uzbekistan - 89 percent.

${ }^{5}$ The situation may change. In the wake of the shootouts between the police and armed Islamists in the Uzbek capital in summer 2009, the Central Asian authorities have been alarmed by the resurgence of activities of the IMU militants.

${ }^{6}$ One of the longstanding sources of row in the Uzbek/Tajik relations is the divergent interpretation of national historiographies and competing claims to Bukhara and Samarkand. (for further discussion, see Torbakov, 2001). 


\section{References}

Abdullaev, Zafar (2004). “Tajikistan: Guilty by Association”, Reporting Central Asia, 20

May, URL (consulted May 2007): http://iwpr.net/?p=rca\&s=f\&o=176252\&apc _state $=$ henirca2004.

Ahmedova, F. and Leitich, K. (2001). "Ethnic and Religious Conflict in the Ferghana Valley", Journal of Central Asian Studies 6(1): 33-43.

Allsen, Thomas T. (1997). Commodity and Exchange in the Mongol Empire. A Cultural History of Islamic Textiles. Cambridge: Cambridge University Press.

Amirkulov, T. (2005). “Tadzhiki v Uzbekistane - Ne Diaspora.” 15 November, URL (consulted Jan. 2008): http://centrasia.org/newsA.php4?st=1132006080.

Amnesty International (2005). "Europe and Central Asia: Summary of Amnesty International's Concerns in the Region. July - December 2004", AI, EUR 01/01/2005, URL (consulted Jun. 2008): http://web.amnesty.org/library/Index/ ENGEUR010022005?open\&of=ENG-345.

Azimov, Dadodjan (2006). "Are Islamic Militants Regrouping in the Fergana Valley?" Reporting Central Asia, 1 December, URL (consulted May 2008): http://iwpr.net/?p $=\mathrm{rca} \& \mathrm{~s}=\mathrm{f} \& \mathrm{o}=325860 \& \mathrm{apc} \_$state $=$henprca

Babadzhanov, B. (2001). "On the Activities of Hizb at-Takhrir Islami in Uzbekistan," in A. Malashenko and M.B. Olcott (eds), Islam in the Post-Soviet Newly Independent States: the View from Within. Moscow: Carnegie Moscow Center.

Bayat, A. (2005). "Islamism and Social Movement Theory", Third World Quarterly 26(6): 891-908. 
Benford, R.D. and Snow, D.A. (2000). "Framing Processes and Social Movements: An Overview and Assessment", Annual Review of Sociology 26: 611-639

Botobekov, Uran (2001). "Spreading the Ideas of the Hizb at-Takhrir Islami in South Kyrgyzstan," in A. Malashenko and M.B. Olcott (eds), Islam in the Post-Soviet Newly Independent States: the View from Within. Moscow: Carnegie Moscow Center.

Chandler, Jennifer (2005). "The Explanatory Value of Social Movement Theory", Strategic Insights IV, 5(May), URL (consulted Dec. 2007): http://www.ccc.nps.navy.mil/si/2005/May/ chandlerMay05.pdf.

CIS World Fact Book (2008). URL (consulted Dec. 2008): https://www.cia.gov/library/publications/the-world-factbook/index.html.

Corley, Felix (2004). “Turkmenistan: Why Was Former Chief Mufti Given Long Jail Term?" Forum18, 8 March.

Djuraev, Ulugbek (2006). "Kyrgyzstan Declares War on Imams”, Global Challenge Research, 31 August, URL (consulted Dec. 2007): http://www.axisglobe.com/ article. asp? article $=1049$.

Esposito, John (2005). Islam: The Straight Path. Oxford University Press.

Firdavsi (2006). "Spetsoperatsii na Yuge Kirgizstana: Voina Protiv Terrorisma ili Ohota za Inakomyslyaschimi?" Muslim Uzbekistan, 24 August, URL (consulted Dec. 2007): http://muslimuzbekistan.net/ru/centralasia/mediawatch/story.php?ID=6437.

Giddens, Anthony (1997). Sociology, $3^{\text {rd }}$ ed. Cambridge: Polity Press.

Hafez, Mohammed M. (2003). Why Muslims Rebel: Repression and Resistance in the Islamic World. Bolder, CO: Lynne Rienner. 
Human Rights Watch (1998). "Leninabad: Crackdown in the North”, HRW D1002 10, no. 2, URL (consulted Jan. 2008): http://www.hrw.org/reports98/tajikistan/.

Human Rights Watch (1999). “Kyrgyzstan: Human Rights Developments”, World Report 1999, URL (consulted Jan. 2008): http://www.hrw.org/wr2k/Eca-13.htm.

Human Rights Watch (2002). “Uzbekistan: Human Rights Developments”, World Report 2002, URL (consulted Dec. 2007): http://hrw.org/wr2k2/europe13.html.

Hunter, Shireen (2001). "Religion, Politics, and Security in Central Asia", SAIS Review 21(2): 65-90.

Hunter, Shireen (2002). Uzbekistan: An Overview. WRITENET Paper No.5. Center for Strategic and International Studies, USA.

Institute for War and Peace Reporting (2005). "Clampdown on Islamic Teaching in Turkmenistan”, Reporting Central Asia, 4 August, URL (consulted Dec. 2007): http://iwpr.net/?p=rca\&s=f\&o=255894\&apc_state=henirca2005.

ICG (2003a). "Radical Islam in Central Asia: Responding to Hizb ut-Tahrir”, Asia Report no. 58. Osh/Brussels.

ICG (2003b). "Central Asia: Islam and the State”, Asia Report no.59. Osh/Brussels.

ICG (2004) “Tajikistan's Politics: Confrontation or Consolidation?” Asia Briefing no. 33. Osh/Brussels.

ICG (2009) “Women and Radicalization in Kyrgyzstan.” Asia Report no. 176.

Karagiannis, Emmanuel (2005). "Political Islam and Social Movement Theory: The Case of Hizb ut-Tahrir in Kyrgyzstan”, Religion, State and Society 33(2): 137-50.

Khalid, Adeeb (2007). Islam after Communism: Religion and Politics in Central Asia. Berkeley, CA: University of California Press. 
Khawaja, Marwan (1993). "Repression and Popular Collective Action: Evidence from the West Bank”, Sociological Forum 8(1): 47-71.

Khamidov, Alisher (2002) "Na Yuge Kirizstana Uhudshilis' Otnosheniya Mezhdu Kyrgyzami i Etnicheskimi Uzbekami”, Ferghana.ru, 20 November, URL (consulted Dec. 2007): http://www.ferghana.ru/article.php?id=1101.

Kimmage, D. (2006). "Extremist Threats, and Doubts, in Kyrgyzstan, Tajikistan", RFE/RL, 24 July, URL (consulted Apr. 2008): http://www.rferl.org/ featuresarticle/2006/07/212f8957-a0bf-4963-aacb-0efe6fbf28a5.html

Klyashtorny, S.G. and Sultanov, T.I. (1992). Kazakhstan: Letopis' Treh Tysyacheleti. Almaty, Kazakhstan.

Krueger, A. and Maleckova, J. (2003). "Education, Poverty, and Terrorism: Is There a Causal Connection?” Journal of Economic Perspectives 17(4): 119-44.

Lichbach, Mark I. (1987). "Deterrence or Escalation? The Puzzle of Aggregate Studies of Repression and Dissent”, Journal of Conflict Resolution 31(2): 266-97

Lubin, N. and Rubin, B.R. (1999). Calming the Ferghana Valley: Development and Dialogue in the Heart of Central Asia. New York: The Century Foundation Press. Malashenko, A. and Olcott, M.B. (eds) (2001). Islam in the Post-Soviet Newly Independent States: the View from Within. Moscow: Carnegie Moscow Center.

Marshall, M. and Jaggers, K. (2001). "Polity IV Project: Political Regime Characteristics and Transitions, 1800-1999”, Data users manual, URL (consulted Dec. 2008): http://www.cidem.umd.edu/inscr/polity/polreg.htm.

Meijer, R. (2005). “Taking the Islamist Movement Seriously: Social Movement Theory and the Islamist Movement", International Review of Social History 50(2): 279-91. 
Miloslavski, G. (2001). Wahhabism v Ideologii i politike Musul'manskih Stran. Moscow: "Kraft+".

Moore, Will H. (1998). "Repression and Dissent: Substitution, Context, and Timing”, American Journal of Political Science 42(3): 851-73

Mukhametrakhimova, Saule (2006). 'Perception and Treatment of the 'Extremist' Islamic Group Hizb ut-Tahrir by Central Asian Governments", China and Eurasia Forum Quarterly 4(2): 49-54.

Muller, E.N. and Weede, E. (1990). "Cross-National Variation in Political Violence: A Rational Action Approach”, Journal of Conflict Resolution 34(4): 624-51.

Naumkin, Vitaly V. (2003). "Militant Islam in Central Asia: The Case of the Islamic Movement of Uzbekistan”. Berkeley Program in Soviet and Post Soviet Studies Working Paper Series, URL (consulted Jan. 2008): http://repositories.cdlib.org/ iseees/bps/2003_06-naum.

Naumkin, Vitaly (2005). Radical Islam in Central Asia: Between Pen and Rifle. Oxford: Rowman \& Littlefield Publishers, Inc.

Parker, K., Heindel, A. and Branch, A. (2000). "Armed Conflict in the World Today: Tajikistan.” Humanitarian Law Project/International Educational Development and Parliamentary Human Rights Group (UK), URL (consulted Jan. 2008): http://www.webcom.com/hrin/parker/tajikistan.html.

Piazza, James A. (2006). "Rooted in Poverty?: Terrorism, Poor Economic Development and Social Cleavages", Terrorism and Political Violence 18(1): 219-37.

Open Society Institute (1998). Tajikistan: Refugee Reintegration and Conflict Resolution. New York: Open Society Institute. 
Ponomarev, Vitali and Jukeyeva, Saltanat (2002). "The Religious Factor in the Political Life of Kazakhstan (1991-6)", presented at a round table discussion at the International Eurasian Institution of Economic and Political Research, Washington, DC.

Rashid, Ahmed (2001). "The Fires of Faith in Central Asia", World Policy Journal, 22 March.

Rashid, Ahmed (2002). Jihad: The Rise of Militant Islam in Central Asia. New Haven, CT: Yale University Press.

Rotar, Igor (2004a). “Kazakhstan: Religious Freedoms Survey”, Forum 18, 10 February, URL (consulted Jan. 2008): http://www.forum18.org/Archive.php?article_id=249

Rotar, Igor (2004b). "Kazakhstan: Mosques Resist Pressure to Join State-Recognized Central Organization", Forum 18, 13 February, URL (consulted Jan. 2008): http://www.religioscope.info/article_262.shtml

Rotar, Igor (2004c). "Turkmenistan: State Interference with Islamic Religious Life in the North East", Forum 18, 4 March, URL (consulted Jan. 2008): http://www.forum18.org/Archive.php?article id=268

Rotar, Igor (2005). "Kazakhstan Introduces New Efforts to Suppress Religious Extremism", Eurasia Daily Monitor 2(17), URL (consulted Aug. 2008): http://www.jamestown.org/edm/article.php?article_id=2369144

Rotar, Igor (2006). “The Islamist Underground in Southern Kyrgyzstan”, Terrorism Monitor 4(23): 10-12.

Ro'i, Yaacov (2000). Islam in the Soviet Union: From the Second World War to Gorbachev. New York: Columbia University Press. 
Roy, Oliver (2000). The New Central Asia: The Creation of Nations. New York: New York University Press.

Sagdeev, Roald (2000). “Central Asia and Islam: An Overview”, in R. Sagdeev and S. Eisenhower (eds), Islam and Central Asia: An Enduring Legacy or an Evolving Threat? Washington, DC: Center for Political and Strategic Studies.

Shpekbaev, A. (2005). "Protivodeistvie Vyzovam I Ugrozam XXI Veka”, Ministry of the Internal Affairs of the Republic of Kazakhstan, 28 March, URL (consulted Dec. 2008): http://www.mvd.kz/index.php?p=razdel_more\&id5=145\&id1=7

Snyder, David and Tilly, Charles (1972). "Hardship and Collective Violence in France 1830-1960", American Sociological Review 37(October): 520-32.

Szayna, Thomas S. (2003). "Potential for Ethnic Conflict in the Caspian Region”, in 0. Oliker and T.S. Szayna (eds), Faultlines of Conflict in Central Asia and the South Caucasus: Implications for the US Army. Santa Monica, CA: RAND.

Torbakov, Igor (2001). “Uzbek-Tajik Relations: Divergent National Historiographies Threaten to Aggravate Tensions", Eurasianet.org, 12 June, URL (consulted Jun. 2008): http://www.eurasianet.org/departments/culture/articles/eav061201.shtml.

UNICEF (2007). The State of the World's Children, 2008. URL (consulted Jan. 2009): http://www.unicef.org/sowc08/docs/sowc08.pdf

United Nations (2007). Millennium Development Goals Indicators Online. MDGInfo 2007. URL (consulted Dec. 2008): http://www.devinfo.info/mdginfo2007/

U.S. Department of State. Bureau of Democracy, Human Rights, and Labor (2001). "Uzbekistan, Country Reports on Human Rights Practices”, 23 February 23, URL (consulted Jan. 2008): http://www.state.gov/g/drl/rls/hrrpt/2000/eur/858.htm. 
Wiktorowicz, Q. (2002). "Social Movement Theory and the Study of Islamism: A New Direction for Research", Mediterranean Politics 7(3), 187-211.

Wiktorowicz, Q. (2004a). "Joining the Cause: Al-Muhajiroun and Radical Islam", presented at "The Roots of Islamic Radicalism" Conference, Yale University, 8-9 May.

Wikorowicz, Q. (ed) (2004b). Islamic Activism: A Social Movement Theory Approach. Bloomington, IN: Indiana University Press.

World Bank (2004). Dimensions of Poverty in Kazakhstan. Vol. II: Profile of Living Standards in Kazakhstan in 2002. Report No. 30294-KZ (Poverty Reduction and Economic Management Unit. Europe and Central Asia Region, 9 November.

Yerekesheva, Laura (2004). "Religious Identity in Kazakhstan and Uzbekistan: GlobalLocal Interplay”, Strategic Analysis 28(4): 577-88.

Zhusupov, Sabit (2001). "Islam v Kazakhstane: Proshloe, Nastoyaschee, Buduschee vo Vzaimootnosheniyah Gosudarsva i Religgii", in A. Malashenko and M.B. Olcott (eds), Islam in the Post-Soviet Newly Independent States: the View from Within. Moscow: Carnegie Moscow Center. 
Table 1. Ethnic Composition of Central Asian States

\begin{tabular}{|c|c|c|c|c|c|c|c|}
\hline $\begin{array}{l}\text { Country/ } \\
\text { Province }\end{array}$ & $\begin{array}{c}\text { Uzbeks } \\
\%\end{array}$ & $\begin{array}{c}\text { Tajiks } \\
\%\end{array}$ & $\begin{array}{c}\text { Kyrgyz } \\
\%\end{array}$ & $\begin{array}{c}\text { Turkmen } \\
\%\end{array}$ & $\begin{array}{c}\text { Kazakh } \\
\%\end{array}$ & $\begin{array}{c}\text { Russians } \\
\%\end{array}$ & $\begin{array}{l}\text { Population } \\
\text { (millions) }\end{array}$ \\
\hline Uzbekistan & 75.8 & $4.8^{\mathrm{a}}$ & 0.9 & 0.6 & 4.2 & 6.0 & 23.0 \\
\hline $\begin{array}{c}\text { - Ferghana } \\
\text { Valley }\end{array}$ & 84.2 & 5.0 & 4.2 & & & 3.0 & 6.2 \\
\hline - Andijan & 85.0 & 1.4 & 4.2 & & & 3.9 & 2.0 \\
\hline - Ferghana & 83.6 & 5.5 & 2.1 & & & 4.9 & 2.4 \\
\hline - Namangan & 84.1 & 8.8 & 1.1 & & & 1.9 & 1.7 \\
\hline Tajikistan & 24.8 & 68.4 & 1.3 & $\mathrm{n} / \mathrm{a}$ & 0.4 & 3.2 & 5.9 \\
\hline - Sugd & 31.3 & 56.9 & 1.2 & & & 6.5 & 1.8 \\
\hline Kyrgyzstan & 14.2 & 0.8 & 60.3 & $\mathrm{n} / \mathrm{a}$ & 0.9 & 15.7 & 4.7 \\
\hline $\begin{array}{c}\text { - Ferghana } \\
\text { Valley }\end{array}$ & 26.7 & 1.6 & 73.5 & & & 2.7 & 2.5 \\
\hline - Osh & 28.0 & 2.1 & 63.8 & & & 2.4 & 1.5 \\
\hline -Jalalabad & 24.5 & 0.6 & 67.3 & & & 3.3 & 0.9 \\
\hline - Osh City & 40.9 & 0.4 & 29.1 & & & $\mathrm{n} / \mathrm{a}$ & 0.2 \\
\hline Kazakhstan & 3.7 & 0.2 & $\mathrm{n} / \mathrm{a}$ & $\mathrm{n} / \mathrm{a}$ & 53.4 & 30.0 & 8.0 \\
\hline Turkmenistan & 9.8 & $\mathrm{n} / \mathrm{a}$ & $\mathrm{n} / \mathrm{a}$ & 78.5 & 2.1 & 5.2 & 3.6 \\
\hline
\end{tabular}

${ }^{\mathrm{a}}$ This figure underreports the actual number of ethnic Tajiks in Uzbekistan. In the past, the Soviet censuses identified the residents of Uzbekistan as Uzbeks irrespective of their ethnicity. Today, many Tajiks identify themselves as Uzbeks to avoid social 
Omelicheva, Mariya Y. Ethnic Dimension of Religious Extremism and Terrorism in Central Asia, International Political Science Review, 2010 31(2): 167-186. Publisher's Official Version: <http://dx.doi.org/10.1177/0192512110364738>.

Open Access Version: <http://kuscholarworks.ku.edu/dspace/>.

discrimination and governmental restrictions of educational and employment opportunities (Hunter, 2002).

Source: Lubin and Rubin, 1999: 35; Szayna, 2003: 153-7. 
Table 2. Socio-Economic and Political Conditions in Central Asia

\begin{tabular}{|c|c|c|c|c|c|c|c|}
\hline & $\begin{array}{c}\text { GNI } \\
\text { per } \\
\text { capita } \\
\text { (\$US), } \\
2006\end{array}$ & $\begin{array}{c}\text { GDP } \\
\text { per } \\
\text { capita } \\
\text { average } \\
\text { annual } \\
\text { growth } \\
\text { rate } \\
(\%), \\
1990- \\
2006\end{array}$ & $\begin{array}{c}\text { Average } \\
\text { annual } \\
\text { rate of } \\
\text { inflation } \\
(\%), \\
1990- \\
2006\end{array}$ & $\begin{array}{c}\text { \% of } \\
\text { population } \\
\text { below } \\
\text { US\$1 a } \\
\text { day, } \\
1995-2005\end{array}$ & $\begin{array}{c}\text { Employment } \\
\text { to } \\
\text { population } \\
\text { ratio }(\%), \\
\text { both sexes } \\
\text { (15+ years } \\
\text { old), } 2006\end{array}$ & $\begin{array}{c}\text { Total } \\
\text { adult } \\
\text { literacy } \\
\text { rate, } \\
2000 \text { - } \\
2005\end{array}$ & $\begin{array}{c}\text { Level of } \\
\text { democracy, } \\
2006 \\
\text { (POLITY } \\
\text { IV score on } \\
\text { democracy) }^{\mathrm{a}}\end{array}$ \\
\hline Kazakhstan & 3690 & 2.6 & 83 & $<2$ & 64.7 & 100 & 0 \\
\hline Kyrgyzstan & 490 & -0.9 & 51 & $<2$ & 58.7 & 99 & 3 \\
\hline Tajikistan & 390 & -3.1 & 109 & 7 & 47.9 & 100 & 1 \\
\hline Turkmenistan & 1340 & -6.8 & 408 & 12 & 59.6 & 99 & 0 \\
\hline Uzbekistan & 610 & 0.7 & 117 & $<2$ & 57.7 & $\mathrm{n} / \mathrm{a}$ & 0 \\
\hline
\end{tabular}

${ }^{a}$ Polity IV democracy index is an eleven-point scale (0-10) measure of institutionalized democracy derived from the scores on the competitiveness of political participation, the openness and competitiveness of executive recruitment, and constrains on the chief executive (Marshall and Jaggers 2001). In this index, "0" stands for the lowest possible level of democracy.

Sources: UNICEF, 2007; United Nations, 2007. 